\title{
RELIABILITA A FAKTOROVÁ VALIDITA DOTAZNÍKU SPARO
}

\author{
Hynek Cígler, Adéla Rudá
}

\begin{abstract}
Abstrakt
V roce 2009 patřil dotazník SPARO k nejpoužívanějším metodám psychologické diagnostiky v ČR (Urbánek, 2010), a to zejména mezi psychology působícími v personalistice, vězeňství, policii a armádě. Empirické důkazy jeho validity a reliability ovšem chybějí. S využitím rozsáhlého vzorku policistů a uchazečů o práci u policie jsme proto ověřili reliabilitu a faktorovou validitu dotazníku. Výsledky ukazují, že vnitřní konzistence je neuspokojivá u zhruba poloviny škál, jednotlivé škály navíc nejsou jednodimenzionální. Faktorová validita je problematická zejména u hlavních komponent dotazníku, které spolu oproti předpokladům silně korelují. Tyto korelace navíc byly přítomny i v původních standardizačních vzorcích, protože se neliší námi pozorované a originální korelační matice. Faktorová struktura dvou „obecnějších faktorů“ je komplikovaná, nelze v rozporu s teorií identifikovat dvě nezávislé latentní proměnné. Výsledky nepodporují využití dotazníku $\mathrm{v}$ běžné praxi. Za tímto účelem by bylo nezbytné prokázat prediktivní validitu jednotlivých škál dotazníku; souběžnou validitu ověřujeme v další studii (Cígler \& Rudá, 2021).
\end{abstract}

Klíčová slova: vnitřní konzistence; faktorová validita; SPARO; policejní sbor ČR; personální výběr

\section{THE RELIABILITY AND FACTOR VALIDITY OF THE SPARO QUESTIONNAIRE}

\begin{abstract}
In 2009, the SPARO questionnaire was one of the most used assessment methods in the Czech Republic (Urbánek, 2010), especially between psychologists in human resources, prisons, police, or the army. However, empirical evidence of its reliability and validity is missing. Using a significant sample of police officers and applicants to police, we researched the questionnaire's reliability and factor validity. About half of the scales do not have adequate internal consistency; the majority of them are not unidimensional. Factor validity is questionable, especially in the main components of the questionnaire, which are highly correlated. These correlations were also present in the original standardized samples as our and original correlation matrices do not differ. The factor structure of the two general factors items is not clear and two-dimensional. Our results do not support the use of the questionnaire in practice. It is necessary to confirm its' predictive validity; the criterion validity is evaluated in our follow up study (Cígler \& Rudá, 2021).
\end{abstract}

Keywords: internal consistency; factor validity; SPARO; Police of the Czech Republic; personal selection

Došlo: 18. 7. 2020

Schváleno: 10.11. 2020 


\section{Úvod}

Cílem této studie je posouzení faktorové validity a reliability dotazníkové baterie SPARO (Mikšík, 2004). V České republice jde společně s jejími předchozími verzemi o velmi rozšířenou metodu, která v nedávné době patřila dokonce k nejpoužívanějším tuzemským dotazníkům (Svoboda et al., 2004; Urbánek, 2010). Bohužel, není nám známa žádná nezávislá studie, která by psychometrické parametry dotazníku ověřovala. V databázích Web of Science a Scopus se k 3. dubnu 2020 nacházely jen tři studie, které využily některý z rodiny testů SPARO, IHAVEZ, SPIDO, VAROS nebo IHARO (Jurišová \& Sarmány-Schuller, 2013; Preiss \& Haas, 1997; Šucha et al., 2017). Pouze Preiss a Haas (1997) se však explicitně zabývali psychometrickými parametry metody.

Dotazník SPARO je naopak značně populární v diplomových pracích. Databáze theses.cz k 3. dubnu 2020 obsahovala v kombinaci s termínem „dotazník“ 964 výsledků obsahujících slovo SPARO. Je však otázkou, kolik z nich se zabývá psychometrickými parametry těchto metod.

\section{Východiska metody SPARO: bazální psychická autoregulace osobnosti}

Osobnostní dotazník SPARO vychází z teorie osobnosti Oldřicha Mikšíka (2003, 2007, 2009) operacionalizované do celé řady dotazníků. Naneštěstí jsou Mikšíkovy texty psané hůře srozumitelným stylem, což znesnadňuje porozumění celé teorii. Řada publikací navíc obsahuje prakticky shodné pasáže, výzkumné vzorky se nejasným způsobem prolínají a analytické postupy nejsou dobře dokumentované. Navíc se použitá terminologie značně odlišuje od pojmů současné psychologie individuálních rozdílů (např. Leary \& Hoyle, 2009), což skýtá obtíže při ověřování konstruktové validity Mikšíkových dotazníků. To vše je jednoznačně škoda; Mikšík nabídul ucelený pohled na strukturu psychiky člověka, který se zdá být významně odlišný od jiných současných teorií osobnosti, a který by tak mohl být značným př́nosem.

Mikšík se každopádně vymezuje proti tradičním pojetím psychologických teorií osobnosti a svůj koncept, který nazývá ,, bazální psychická autoregulace osobnosti“, definuje jako ,,integrovanou slitinu vrozených a osvojených strategii, jimiž se subjekt v procesu své reálné životní praxe dynamicky vyrovnává s různorodými variantami situačních komplexü“ (Mikšík, 2007, p. 58).

I přes jistou pojmovou nejasnost je tato definice v souladu se současným pojetím osobnosti jako souhrnu kognitivních, behaviorálních a afektivních vzorců, které vznikají na podkladě biologických i environmentálních př́íin (např. Corr \& Matthews, 2009). Podle Mikšíka (2007, pp. 59-60) jsou povahové vlastnosti „slitinou čtyř na sobě relativně nezávislých komponent" (pro přehled viz Tabulka 1), které jsou dále modifikovány „,faktory vyššiho řádu“ ve „dvou na sobě nezávislých, kvalitativně rozdilných aspektech“ (Tabulka 1). Tato struktura je označována jako „struktura psychické variabilnosti“ a jednotlivé psychické rysy jako „,variabilita“, protože se „,... ve všech komponentách [...] specifickým [...] způsobem prosazuje dynamický [...] aspekt, [a] to na kontinuu od maximální stability [...], přes relativně vyrovnanou [...] hodnotu, až po maximální variabilnost“. (Mikšík, 2007, pp. 59-60). 


\section{Tabulka 1}

Základni komponenty bazální psychické integrovanosti a Bazálnějši škály obecné variability

kladný pól

záporný pól

\section{Základni komponenty}

KO - kognitivní variabilnost

EM - emocionální variabilnost

$\mathrm{RE}$ - regulační variabilnost

$\mathrm{AD}$ - adjustační variabilnost tendence ke změně, tíhnutí $\mathrm{k}$ vysoké kvantitě, dynamice a proměnlivosti vnějších podnětů při komplexním zpracování

vysoká emocionální vzrušivost, sklon k prožívání situační tenze i euforie

nízké sebeovládání, nízké zvažování důsledků chování

tendence odpovídat na situační proměnné přizpůsobovacími aktivitami tendence $\mathrm{k}$ interakci se stabilnějším a kognitivně chudším prostředím

emocionální stabilita, snížená emotivita

soustavné vřazování budoucího možného efektu do rozhodovacích procesů tendence přidržovat se vlastních př́istupů, schémat chování

Bazálni škály (faktory vyššího řádu či obecnějši faktory) ${ }^{l}$

PV - obecná hladina psychické vzrušivosti

MH - motorická hybnost tíhnutí $\mathrm{k}$ dynamickým interakcím s vysokou situační vzrušivostí

vyhledávání změn při menších regulačních zábranách a emocionální a adjustační rigiditě nízké vyhledávání dynamických interakcí

vyhledávání klidu při vysoké emocionální vzrušivosti, regulovanosti a přizpůsobivosti

Poznámka: Upraveno podle Mikšíka (2004, 2007).

${ }^{1}$ Pojmenování se liší v různých zdrojích (Mikšík, 1992, 2001, 2004, 2007, 2009).

\section{Dotazník SPARO}

Zkratka SPARO je akronymem pro sousloví Systém bazální Psychické AutoRegulace Osobnosti. Tento osobnostní dotazník je součástí programu DIAROS a navazuje na předchozí řadu taktéž oblíbených (Svoboda et al., 2004; Urbánek, 2010) dotazníků IHAVEZ, SPIDO, VAROS a IHARO, ze kterých bezprostředně vychází (Mikšík, 2004). Ty se zaměřují na zjišt’ování takových kvalit osobnosti, které jsou potřebné pro zvládání náročných situací, a dále sleduje takové charakteristiky, které pro lidi mohou představovat optimální nebo nadměrnou kvalitu či intenzitu životních podmínek, okolností a životních kontextů. Je tedy podle autora vhodný např́ílad v oblasti armády nebo zdravotnictví (Mikšík, 1992). Celá baterie DIAROS je navíc modulární a kromě výše uvedených nástrojů obsahuje i další metody, jako jsou např. BAROM, SUPSO, SIPO či DUSIN (Mikšík, 2009).

Originální dotazník VAROS (Mikšík, 1992) obsahoval 120 položek v sedmi škálách. Navazoval na něj SPIDO (Mikšík, 1992) s 200 položkami a 7 nově přidanými škálami. Poslední je pak IHAVEZ (Mikšík, 1992) se 300 položkami, 14 standardními škálami shodnými s dotazníkem SPIDO a 22 přídavnými škálami. Seznam všech škál těchto dotazníků je v př́loze 1, tabulce 1.1. 
Metoda SPARO obsahuje 300 položek stejně jako IHAVEZ, zařazených do čtyř hlavních komponent, dvou obecnějších faktorů, validizačního L-skóre a 34 subškál rozdělených do sedmi „dimenzi“ - pro přehled viz tabulku 1.2 v prŕíloze 1 (Mikšík, 2004). Konfigurací čtyř základních komponent lze navíc určit 16 typů osobnosti pro usnadnění interpretace výsledků, těmi se však v naší studii nezabýváme.

SPARO má velmi blízko k metodě IHAVEZ, jejíž záznamové archy je dokonce možné převést na škály SPARO, a to kromě škály vztahovačnost, VZ (Mikšík, 2004). Po bližším prozkoumání položek jednotlivých dotazníků je navíc patrné, že většina položek obou dotazníků je shodná, jejich pořadí či znění je však v některých případech pozměněno, některé položky jsou nahrazeny jinými a jiné jsou revertovány; několik položek je vynecháno či nově přidáno (Mikšík, 1992, 2004) ${ }^{1}$. Změny však nejsou v manuálu SPARO explicitně uvedeny a manuál se blíže nevěnuje ani konstrukci, ani revizi položek.

Škály SPARO obsahují různý počet položek (Mikšík, 2004). Čtyři hlavní komponenty a L-skór věrohodnosti 20, obecnější faktory 14, ostatní subškály pak 14-20 položek, pouze škála anomalita (AN) je definována jako vážený součet vybraných subškál. Některé položky jsou zařazeny zároveň do komponent i subškál, některé i do vícera, což může nadhodnocovat odhad korelací jednotlivých skórů a komplikovat odhad faktorových analýz nad škálovými skóry. Položky zařazené do obecnějších faktorů pak sytí vždy alespoň jednu subškálu, čtyři hlavní komponenty však žádné společné položky nesdílejí. Překryvy položek jsou součástí on-line supplementu.

Dotazník SPARO je administrovaný metodou „tužka-papír“ a vyhodnocený ručně pomocí šablon nebo s pomocí programu DiarosWin, případně administrovaný přímo v tomto programu; obě formy jsou považovány za ekvivalentní. Respondent musí zodpovědět vždy všechny položky. Pro interpretaci slouží standardní z-skóre, program navíc nabízí kromě obecných či specifických norem i referenční z-skóre založené na charakteristikách ostatních respondentů vyšetřených daným uživatelem programu DiarosWin (Mikšík, 2001).

\section{Faktorová struktura dotazníku SPARO}

Plný text původních studií (Mikšík, 1983, 1985, cit. dle Mikšík, 2004, 2009), ze kterých vycházejí veškeré další popisy faktorové struktury dotazníku, nám bohužel nebyl dostupný. Vycházíme proto ze sekundárních zdrojů (Mikšík, 2004, 2009), z nichž však není analytický postup zcela srozumitelný.

S pomocí faktorové analýzy nad položkami metody IHAVEZ byly identifikovány čtyři faktory KO, EM, RE a AD. Obdobným způsobem byly identifikovány i faktory vyššího řádu PV a MH zdrojů (Mikšík, 2004, 2009). Po roce 2005 (Mikšík, 2009) byly provedeny nové faktorové analýzy, stáří datového souboru však není jasné - bud' sběr probíhal v letech 1996-2001 (Mikšík, 2004) nebo 2000-2004 (Mikšík, 2009). Každopádně byla použita rotace varimax nad korelační maticí 41 škál, tedy nikoli položek. Tento postup však považujeme za vysoce problematický a jeho závěry za silně

\footnotetext{
${ }^{1}$ Př́kladem revertované položky je „,Nerad se pouštím do riskantních podnikü“ (IHAVEZ) vs. „Rád se pouštím do riskantnich podnikü“ (SPARO). Přeformulovanou položkou je např. ,,Nevyplácí se angažovat se pro druhé; obvykle člověk zjistí, že byl jen zneužit a nikdo to neoceni “ (IHAVEZ) vs. „Nevyplácí se angažovat se pro druhé; obvykle se jen zjistí, že to nikdo neoceni" (SPARO) či „Je lepší, získaji-li manželé prvni sexuálni zkušenosti spolu“ (IHAVEZ) vs. „Je lepší, ziskaji-li manželé takové zaměstnání, při kterém by mohli hodně cestovat po republice.“ (SPARO). Mezi přidané položky patří „Byl bych spokojenějši i úspěšnější, kdyby mi řada lidí nepodrážela nohy“ (nenachází se v IHAVEZ), vynechána naopak byla položka „Naprosté většině neštěstí a katastrof nelze v podstatě zabránit" (nenachází se ve SPARO).
} 
zkreslené právě z toho důvodu, že škály obsahují společné položky, které nadhodnocují jejich korelaci a znehodnocují tak výsledné faktorové řešení.

Extrahovány byly bud' čtyři faktory, které podle Mikšíka $(2004,2009)$ potvrzují existenci čtyř základních komponent, a dále i všechny „statisticky průkazné“ faktory (přičemž není zř̌jmé, co je slovem ,,průkazné“ myšleno), ve kterých byly pozorované faktory normality (sycené zejména škálami AN, EX a L) a interpersonálních postojů (VZ a BE). Navzdory tomu není dle autora třeba revidovat vymezení základních čtyř komponent (Mikšík, 2004, 2009). Autor pak konstatuje (bez dalších důkazů) úspěšné srovnání obecnějších faktorů s původními škálami dotazníku IHAVEZ (Mikšík, 2004). Není však popsán způsob tvorby nových škál metody SPARO, ani jejich návaznost na původní IHAVEZ.

Vzhledem k metodologickým pochybením a nedostatku informací lze proto faktorovou validitu dotazníku SPARO hodnotit jen obtížně. Na základě teorie a způsobu vývoje však lze předpokládat, že čtyři základní komponenty (KO, EM, RE, AD) by měly být jednodimenzionální (protože jsou konstruovány s pomocí faktorových analýz) a „relativně nezávislé“, tedy nekorelované. To stejné by mělo platit i pro obecné faktory PV a MH. Ostatní škály jsou vymezeny „operacionálně“ a unidimenzionalitu tak nelze plně předpokládat.

\section{Reliabilita dotazníku SPARO}

Mikšík (2004) uvádí, že vnitřní konzistence všech skórů dotazníku se v souboru 362 mužů pohybovala v rozmezí 0,46 až 0,81 (Cronbachova alfa). Výjimku podle něj tvořily dvě škály, KI a RF, jejichž reliability jsou 0,24 a 0,29 . Autor nijak nereflektuje to, že většina těchto odhadů je neuspokojivě nízká.

K dispozici jsou rovněž i výsledky test-retest reliability na dvou vzorcích. Korelace čtyř komponent a dvou obecnějších faktorů u pacientek s neurózou $(n=48)$ na začátku léčby a po šesti týdnech dosahovala hodnot 0,56 až 0,87 . U vysokoškolských studentek $(n=157)$ s odstupem dvou let dosahovala test-retest reliabilita šesti zmíněných škál hodnot 0,56-0,86 (Mikšík, 2004). Jiné studie nejsou k dispozici, nebo se nám je nepodařilo nalézt.

\section{Kontext využití metody SPARO v policejní psychologii}

Využití dotazníku SPARO je relativně rozšiřreno v bezpečnostních složkách a armádě. Jedná se o psychicky náročné povolání, které předpokládá určitou odolnost vůči stresu. Psychodiagnostika v rámci personálního výběru tak zohledňuje tento požadavek skrze metodu, která se dle svého autora (Mikšík, 2001, 2004, 2007, 2009) zaměřuje právě na prozkoumání schopnosti zvládat zátěžové situace. Podle výzkumu SPARO využívali kolem roku 2002 jak kliničtí a poradenští psychologové, tak psychologové v organizacích a pracovní psychologii a asi $40 \%$ psychologů v bezpečnostních sborech (Svoboda et al., 2004; Urbánek, 2010), obdobná situace pak byla i v roce 2009 (Urbánek, 2010).

\section{Výzkumné cíle}

Cílem naší studie je ověřit reliabilitu a faktorovou validitu dotazníku SPARO v nezávislé studii na českém vzorku. Za tímto účelem budou využita data z reálné diagnostiky v kontextu personálního výběru a ověřování profesní způsobilosti u členů policejního sboru České republiky. Pokud je nám 
známo, SPARO dosud nebylo podrobeno jiným studiím, než které realizoval autor dotazníku Oldřich Mikšík (1992, 2001, 2003, 2004, 2007, 2009) s několika málo výše uvedenými výjimkami.

Naše výzkumné otázky a hypotézy lze rozdělit do tří oblastí týkajících se reliability, vnitřní struktury (faktorové validity) a zobecnitelnosti.

\section{Reliabilita}

Výzkumná otázka 1. Je dotazník SPARO dostatečně reliabilním nástrojem pro individuální diagnostiku?

Odpovědí na tuto otázku bude ověření vnitřní konzistence všech škál dotazníku SPARO. Kromě prosté deskripce srovnáme pozorované odhady reliability s těmito kritérii: neakceptovatelné $\left(r_{x x}<0,7\right)$, akceptovatelné $\left(0,7 \leq r_{x x}<0,8\right)$, dobré $\left(0,8 \leq r_{x x}<0,9\right)$ a výborné $\left(0,9 \leq r_{x x}\right)$.

\section{Vnitřní struktura metody}

Výzkumná otázka 2. Odpovídá vnitřni struktura a vzájemné vztahy jednotlivých škál dotazníku SPARO teoretickým predpokladüm?

Hlavní komponenty a obecné faktory dotazníku SPARO by měly být syceny jediným faktorem. Jednodimenzionalitu nicméně ověříme u všech škál.

H1: Jednotlivé škály SPARO jsou jednodimenzionální.

Hypotézy H2-H5 se zaměřují přímo na konstruktovou validitu klíčových skórů dotazníku SPARO tak, jak vyplývá z teoretických předpokladů.

H2: Základní komponenty metody SPARO (KO, EM, RE a AD) jsou syceny čtyřmi odlišnými faktory.

H3: Čtyři faktory sytící základní komponenty metody SPARO (KO, EM, RE a AD) jsou vzájemně nezávislé a jejich korelace jsou blízké nule.

H4: Obecnější faktory metody SPARO (PV, MH) jsou syceny dvěma odlišnými faktory.

H5: Dva faktory sytící obecnější faktory metody SPARO (PV, MH) jsou vzájemně nezávislé.

\section{Zobecnitelnost závěrů}

Výzkumná otázka 3. Lze naše výsledky zobecnit na populaci, ze které byl vybrán standardizační vzorek dotazniku SPARO?

Poslední hypotéza je klíčová pro ověření zobecnitelnosti našich závěrů, tedy toho, zda náš vzorek není výrazně odlišný od originálních Mikšíkových (2009) výzkumných souborů.

H6: Pozorované korelace základních komponent, obecnějších škál a škál normality dotazníku SPARO odpovídají korelacím reportovaným autorem metody (Mikšík, 2009, pp. 116-118), a to jak pro muže (H6a), tak i pro ženy (H6b). 


\section{Metoda}

\section{Výzkumný vzorek a procedura}

Pro účely této studie byla využita data získaná v průběhu reálné testové situace, poskytnutá Policejním prezidiem České republiky. Vzorek tvoří NSPARO $=4534$ osob testovaných v letech 20022014 ve výběrové situaci, z toho 1270 žen (28 \%) a 3264 mužů (72 \%). Průměrný věk byl 25,2 roku $(\mathrm{SD}=6,3)$. Celkem $95 \%$ vzorku tvořili uchazeči (civilisté) o služební poměr v policii, 1 \% př́slušníci jiných bezpečnostních sborů přestupující $\mathrm{k}$ policii a $4 \%$ příslušníci policie testovaní v rámci dalšího interního výběru. Celkem 97 \% testování probíhalo za účelem zjištování osobností způsobilosti (všichni uchazeči z řad civilistů, příslušníci jiných bezpečnostních sborů a polovina př́slušníků policie). Z nich $41 \%$ bylo testováno s výsledkem způsobilý k výkonu služby a $59 \%$ s výsledkem nezpůsobilý. Data tohoto výzkumného vzorku tvoří položky, základní demografické údaje a hrubé skóry škál dotazníku SPARO.

Všechna data byla získána během supervidované administrace na počítači nebo v písemné formě vyhodnocené počítačem. Písemná i elektronická verze dotazníku SPARO jsou autorem považovány za ekvivalentní (Mikšík, 2004). Ve všech výpočtech zanedbáváme rozdíly mezi muži a ženami, pokud není explicitně řečeno jinak. To může mírně zkreslit odhad faktorové struktury i reliability, nicméně dle autora by měla být struktura obou metod pro muže a ženy analogická (Mikšík, 1992, 2004, 2009). Navíc i námi pozorované rozdíly v průměrných skórech byly spíše zanedbatelné; 95 \% rozdílů mezi muži a ženami (Kendallovo tau) na všech škálách SPARO bylo v rozmezí 士0,2. Větší efekty než $\pm 0,3$ pak byly pozorovány jen u škály FM (feminní vs. maskulinní interakce), $\tau=-0,32$, což dává věcný smysl.

\section{Statistická analýza dat}

Veškeré analýzy byly provedeny v prostř̌edí R ver. 3.6.2 (R Core Team, 2020) s využitím různých knihoven (T. D. Jorgensen et al., 2020; Lakens, 2017; Mangiafico, 2020; Phillips, 2017; Revelle, 2019; Rosseel, 2012; Signorell \& et al., 2020; Torchiano, 2019; Wickham \& Bryan, 2019). Pro všechny analýzy byla vzhledem k velikosti vzorků a počtu testů zvolena prŕsnější hladina spolehlivosti $\alpha=0,01$. Analytický skript, doplňkové soubory a další materiály jsou veřejně dostupné na https://doi.org/10.17605/OSF.IO/CNU58; tento on-line supplement je sdílený s navazující studií o souběžné validitě s MMPI-2 (Cígler \& Rudá, 2021). Nemáme svolení sdílet zdrojová data, proto je na uvedeném odkazu k dispozici pouze jejich struktura a deskriptivní statistiky včetně korelačních matic (Pearsonových i tetrachorických). Námi použité zařazení položek do škál jsme úspěšně ověřili, pro podrobnosti viz prílohu 2.

\section{Odhad vnitřní konzistence}

Podrobný způsob odhadu vnitřní konzistence tvoří př́ilohu 3, zde jen stručně shrneme podstatu našeho př́stupu. Namísto koeficientu alfa (Cronbach, 1951), který má příliš silné předpoklady (jednodimenzionalitu a tau-ekvivalenci položek, tedy shodné faktorové náboje), př́ jejichž porušení může silně podhodnocovat skutečnou reliabilitu, používáme vyšší ze dvou jiných, méně zkreslených odhadů. Jejich maximum, které je vždy vyšší než Cronbachovo alfa, anotujeme jako $r_{\text {max }}$. Konkrétně jde o koeficient $\lambda_{4}$ (Benton, 2015; Guttman, 1945; Revelle \& Zinbarg, 2009), což je nejvyšší možný odhad split-half reliability, a na explorační faktorové analýze založený Bentlerův koeficient $r_{g l b}(\mathrm{P}$. M. Bentler \& Woodward, 1980; Peter M. Bentler, 2009; Revelle \& Zinbarg, 2009; Sijtsma, 2009). 
Oba odhady lze chápat jako nejmenší možný podíl rozptylu součtového skóru, který je vysvětlen rozptylem sdíleným napříč položkami. Tyto výsledky doplňujeme ještě koeficientem Revellova (1978) $\beta$, který je naopak odhadem nejmenšího možného podílu rozptylu a lze jej vysvětlit jen jediným společným faktorem. U škály Anomálie osobnosti (AN) jsme museli zvolit specifický postup, interpretace jeho výsledku je nicméně analogická výše zmíněné. Postup je podrobně popsán rovněž v Př́loze 3.

\section{Vnitřní struktura testu}

Vnitřní struktura testu bude ověřována s pomocí ordinální konfirmační faktorové analýzy. Ta je ve všech př́padech odhadnuta s využitím knihovny lavaan (Rosseel, 2012) prostřednictvím robustního estimátoru WLSMV nad maticí polychorických korelací. Protože vzhledem k velikosti vzorku je absolutní test dobré shody modelu s daty př́liš striktní, používáme k interpretaci kromě něj i relativní indexy interpretované ve shodě s běžnými doporučeními (Hu \& Bentler, 1999; MacCallum et al., 1996): Tuckerův-Lewisův index, $T L I$ (TLI < 0,90 jako neakceptovatelné; $0,90 \leq T L I<0,95$ jako adekvátní; a 0,95 $\leq T L I$ jako dobré), Standardized Root Mean-square Residual, SRMR $(S R M R>0,08$ jako neakceptovatelné, $0,08 \geq S R M R>0,05$ jako adekvátní; a SRMR $\leq 0,05$ jako dobré) a Root Mean Square Error of Approximation, RMSEA (stejná kritéria jako pro SRMR).

Protože index TLI je závislý na síle vzájemných vztahů položek a má tendenci podhodnocovat shodu modelu s daty, pokud jsou tyto vztahy slabé (Kenny et al., 2014), použili jsme rovněž RMSEA základního modelu, kde jsou všechny faktorové náboje zafixovány na nulu $\left(R M S E A_{\text {null }}\right)$. Ve shodě s Kennym a kol. (2014) TLI neinterpretujeme, pokud je $R M S E A_{\text {null }}<0,158$. RMSEA null bude odhadnuté pomocí funkce nullRMSEA z balíčku semTools (T. D. Jorgensen et al., 2020). Celkové hodnocení modelu bude založeno na nejlepším hodnocení, kterého dosáhly všechny indexy. Kromě toho bude model hodnocen jako dobrý, pokud se signifikantně neliší od dat na hladině $\alpha=0,01$ (nehledě na zbylé indexy). Z hodnocení je vyřazena škála $A N$, u které jednodimenzionalitu nelze předpokládat (jde o vážený součet dílčích škál).

Hypotéza 1 (H1). Jednodimenzionální struktura všech škál bude ověřena pomocí konfirmační faktorové analýzy separátně pro každou škálu.

Hypotézy 2 a 4 (H2, H4). Strukturu hlavních komponent, H2 (resp. obecnějších faktorů, H4) dotazníku SPARO ověřme s pomocí čtyřdimenzionální (resp. dvoudimenzionální) konfirmační faktorové analýzy.

Hypotézy 3 a 5 (H3, H5). Pro ověření nezávislosti hlavních komponent, H3 (resp. obecnějších faktorů, H5) dotazníku SPARO zafixujeme kovariance mezi latentními proměnnými z předchozího modelu (H2, resp. H4) na nulu a oba modely srovnáme s využitím robustního testu poměrů maximální věrohodnosti (Satorra, 2000), který je vhodný i pro ordinální CFA s estimátorem WLSMV (T. Jorgensen, 2020).

\section{Zobecnitelnost závěrů}

Hypotéza 6 (H6). Shodu námi a Mikšíkem (2009) pozorovaných korelací škál dotazníku SPARO ověříme prostřednictvím mnohoskupinové konfirmační faktorové analýzy metodou maximální věrohodnosti (ML) nad předem odhadnutými maticemi Pearsonových korelací, a to pro muže a ženy zvlášt'. První skupinou bude vždy náš vzorek SPARO, druhý bude originální Mikšíkův (2009) vzorek $\left(n_{m u z ̌ i}=8099, n_{\check{e} e n y}=7080\right)$. Korelace budou omezeny na stejné hodnoty např́íc oběma vzorky a 
výsledný model bude interpretován stejně jako v prŕípadě hypotéz H1. Nízká shoda modelu s daty bude znamenat, že se naše a Mikšíkova (2009) data liší.

\section{Výsledky}

\section{Deskriptivní statistiky}

Deskriptivní statistiky všech položek, matice Pearsonových i tetrachorických korelací jsou vzhledem ke svému rozsahu uvedeny v on-line supplementu.

Položky dotazníku SPARO byly zpravidla průměrně obtížné až obtížnější, průměr popularit položek (podílu souhlasných odpovědí) byl $0,44(S D=0,28, M d=0,38)$. Prostředních $50 \%$ popularit se nacházelo v rozmezí $0,22-0,68$, ačkoliv některé položky byly velmi extrémní ( $\min =0,01$, $\max =0,97)$. Histogram popularit položek je zobrazen na Chyba! Nenalezen zdroj odkazů.. Vzhledem k povaze testování v položkovém souboru dotazníku SPARO nechyběla žádná data.

Deskriptivní statistiky celkových skórů dotazníku SPARO jsou uvedeny níže společně s reliabilitou v Tabulka 2, histogramy jednotlivých škál jsou součástí on-line supplementu.
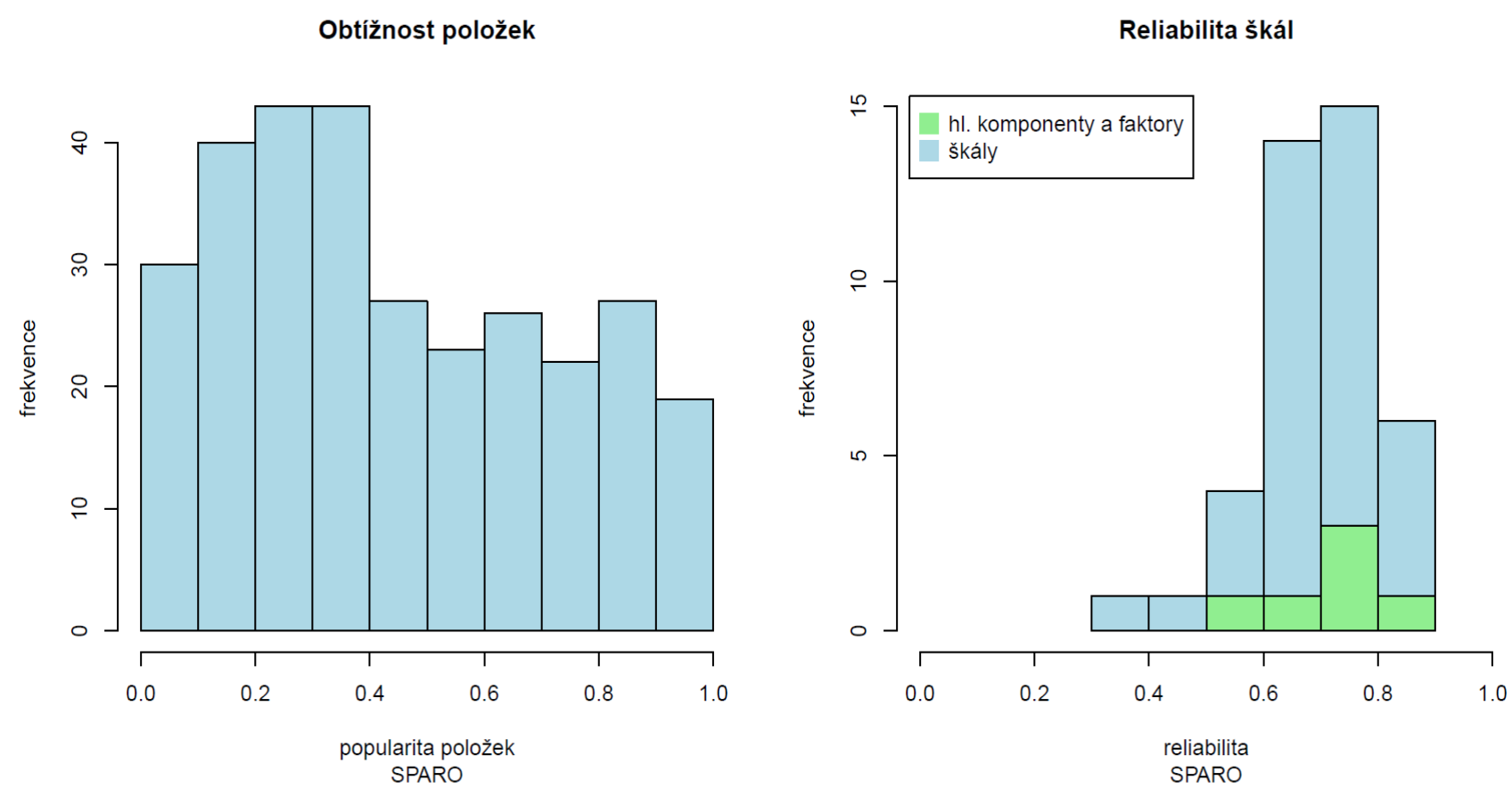

\section{Obrázek 1}

Popularita položek a rozložení reliability jednotlivých škál dotazníku SPARO 


\section{Vnitřní konzistence}

Reliability dotazníku SPARO jsou v Tabulka 2 společně s deskriptivami celkových skórů. Rozložení reliabilit jednotlivých škál je patrné z histogramu na Chyba! Nenalezen zdroj odkazů..

Kromě komponenty $\mathrm{AD}\left(r_{\max }=0,559\right)$ a obecnějšího faktoru MH $\left(r_{\max }=0,636\right)$ měly ostatní hlavní komponenty a obecnější faktory přinejmenším akceptovatelnou reliabilitu; medián byl $M d=0,75$, odhady se pohybovaly v rozmezí $0,56-0,87$. Reliabilita všech skórů, poskytovaných dotazníkem SPARO, se pohybovala v rozmezí $0,32-0,87 \mathrm{~s}$ mediánem $M d=0,71$; medián odhadu prostřednictvím koeficientu alfa byl $\mathrm{v}$ důsledku porušených předpokladů nižší, jen $M d=0,61$. Jako neakceptovatelnou hodnotíme vnitřní konzistenci u 20 (49\%) skórů, u $14(34 \%)$ jako akceptovatelnou a jen u 7 (17 \%) jako dobrou. Žádný skór neměl výbornou vnitřní konzistenci (vyšší než 0,90$)$.

\section{Tabulka 2}

Deskriptivy a vnitřni konzistence škál SPARO

\begin{tabular}{|c|c|c|c|c|c|c|c|c|c|c|c|c|c|}
\hline & $\mathrm{M}$ & SD & $\mathrm{Md}$ & $\min$ & $\max$ & $\mathrm{Sk}$ & $\alpha$ & $\lambda_{4}$ & $r_{g l b}$ & $\beta$ & $\mathrm{nf}$ & $r_{\max }$ & hodnocení $r_{\max }$ \\
\hline \multicolumn{14}{|c|}{ Hlavni komponenty } \\
\hline $\mathrm{KO}$ & 9,24 & 3,60 & 9 & 0 & 20 & 0,081 & 0,698 & 0,753 & 0,746 & 0,555 & 7 & 0,753 & akceptovatelné \\
\hline EM & 4,47 & 3,95 & 4 & 0 & 19 & 1,011 & 0,832 & 0,861 & 0,868 & 0,781 & 8 & 0,868 & dobré \\
\hline $\mathrm{RE}$ & 5,24 & 3,19 & 5 & 0 & 20 & 0,791 & 0,700 & 0,753 & 0,758 & 0,603 & 9 & 0,758 & akceptovatelné \\
\hline $\mathrm{AD}$ & 14,74 & 2,33 & 15 & 3 & 20 & $-0,296$ & 0,471 & 0,559 & 0,540 & 0,203 & 9 & 0,559 & neakceptovatelné \\
\hline \multicolumn{14}{|c|}{ Obecné faktory } \\
\hline PV & 3,64 & 2,50 & 3 & 0 & 14 & 0,691 & 0,677 & 0,732 & 0,749 & 0,564 & 7 & 0,749 & akceptovatelné \\
\hline MH & 6,63 & 2,34 & 7 & 0 & 14 & 0,088 & 0,551 & 0,636 & 0,602 & 0,411 & 5 & 0,636 & neakceptovatelné \\
\hline \multicolumn{14}{|c|}{$N-$ Normalita } \\
\hline $\mathrm{VZ}$ & 5,60 & 2,18 & 5 & 0 & 14 & 0,421 & 0,504 & 0,604 & 0,600 & 0,308 & 6 & 0,604 & neakceptovatelné \\
\hline LS & 14,67 & 3,15 & 16 & 1 & 18 & $-1,242$ & 0,780 & 0,818 & 0,838 & 0,694 & 8 & 0,838 & dobré \\
\hline $\mathrm{AN}$ & $-0,07$ & 1,79 & $-0,28$ & $-4,46$ & 12,51 & 0,857 & 0,637 & 0,707 & 0,804 & 0,455 & 39 & 0,804 & dobré \\
\hline EX & 3,57 & 1,80 & 3 & 0 & 15 & 0,697 & 0,286 & 0,399 & 0,453 & $-0,017$ & 9 & 0,453 & neakceptovatelné \\
\hline \multicolumn{14}{|c|}{$L-S k o ́ r$ věrohodnosti podávaných výpovědi } \\
\hline $\mathrm{L}$ & 2,25 & 1,66 & 2 & 0 & 16 & 1,189 & 0,357 & 0,441 & 0,505 & 0,180 & 9 & 0,505 & neakceptovatelné \\
\hline \multicolumn{14}{|c|}{ S-Optimální hladina stimulace } \\
\hline SI & 7,80 & 2,81 & 8 & 1 & 17 & 0,184 & 0,583 & 0,680 & 0,684 & 0,349 & 7 & 0,684 & neakceptovatelné \\
\hline IP & 6,29 & 2,97 & 6 & 0 & 17 & 0,540 & 0,632 & 0,715 & 0,708 & 0,431 & 8 & 0,715 & akceptovatelné \\
\hline $\mathrm{PN}$ & 9,18 & 3,73 & 9 & 0 & 19 & 0,086 & 0,755 & 0,805 & 0,792 & 0,650 & 8 & 0,805 & dobré \\
\hline DI & 6,98 & 2,82 & 7 & 0 & 17 & 0,291 & 0,549 & 0,631 & 0,620 & 0,322 & 7 & 0,631 & neakceptovatelné \\
\hline $\mathrm{SD}$ & 5,64 & 2,80 & 5 & 0 & 18 & 0,759 & 0,636 & 0,688 & 0,684 & 0,499 & 8 & 0,688 & neakceptovatelné \\
\hline OS & 4,14 & 3,48 & 3 & 0 & 19 & 1,121 & 0,788 & 0,828 & 0,823 & 0,672 & 7 & 0,828 & dobré \\
\hline
\end{tabular}




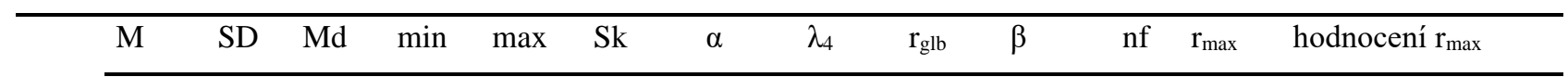

$R$ - tendence riskovat

\begin{tabular}{|c|c|c|c|c|c|c|c|c|c|c|c|c|c|}
\hline AS & 9,59 & 2,69 & 10 & 0 & 18 & $-0,013$ & 0,528 & 0,619 & 0,595 & 0,271 & 8 & 0,619 & neakceptovatelné \\
\hline $\mathrm{AC}$ & 11,79 & 2,88 & 12 & 1 & 18 & $-0,484$ & 0,612 & 0,688 & 0,687 & 0,367 & 6 & 0,688 & neakceptovatelné \\
\hline $\mathrm{TN}$ & 4,87 & 2,99 & 4 & 0 & 18 & 0,974 & 0,681 & 0,737 & 0,764 & 0,529 & 8 & 0,764 & akceptovatelné \\
\hline SE & 9,63 & 3,21 & 9 & 0 & 20 & 0,343 & 0,687 & 0,755 & 0,746 & 0,490 & 8 & 0,755 & akceptovatelné \\
\hline OR & 3,52 & 2,25 & 3 & 0 & 12 & 0,754 & 0,605 & 0,658 & 0,737 & 0,478 & 7 & 0,737 & akceptovatelné \\
\hline
\end{tabular}

I- Účinná integrovanost

\begin{tabular}{|c|c|c|c|c|c|c|c|c|c|c|c|c|}
\hline 5,14 & 3,54 & 4 & 0 & 19 & 0,853 & 0,785 & 0,817 & 0,833 & 0,736 & 9 & 0,833 & dobré \\
\hline 3,86 & 2,93 & 3 & 0 & 18 & 1,071 & 0,718 & 0,760 & 0,772 & 0,619 & 8 & 0,772 & akceptovatelné \\
\hline 14,80 & 3,52 & 15 & 1 & 20 & $-0,757$ & 0,754 & 0,793 & 0,796 & 0,636 & 8 & 0,796 & akceptovatelné \\
\hline 15,15 & 2,75 & 16 & 4 & 20 & $-0,728$ & 0,610 & 0,677 & 0,675 & 0,470 & 8 & 0,677 & neakceptovatelné \\
\hline 15,78 & 2,97 & 17 & 2 & 20 & $-1,310$ & 0,759 & 0,805 & 0,802 & 0,643 & 9 & 0,805 & dobré \\
\hline
\end{tabular}

$V-v z$ tahová dimenze

\begin{tabular}{|c|c|c|c|c|c|c|c|c|c|c|c|c|c|}
\hline KT & 3,89 & 2,77 & 3 & 0 & 18 & 1,114 & 0,677 & 0,726 & 0,767 & 0,573 & 9 & 0,767 & akceptovatelné \\
\hline $\mathrm{BE}$ & 9,13 & 1,83 & 9 & 3 & 14 & $-0,231$ & 0,197 & 0,323 & 0,296 & $-0,171$ & 6 & 0,323 & neakceptovatelné \\
\hline $\mathrm{KN}$ & 11,14 & 2,77 & 11 & 2 & 19 & $-0,086$ & 0,515 & 0,601 & 0,608 & 0,272 & 8 & 0,608 & neakceptovatelné \\
\hline $\mathrm{NE}$ & 10,72 & 2,37 & 11 & 3 & 18 & $-0,007$ & 0,392 & 0,508 & 0,482 & $-0,024$ & 8 & 0,508 & neakceptovatelné \\
\hline
\end{tabular}

K- korektivnost

\begin{tabular}{|c|c|c|c|c|c|c|c|c|c|c|c|c|c|}
\hline RF & 13,60 & 2,31 & 14 & 2 & 19 & $-0,385$ & 0,415 & 0,519 & 0,526 & 0,010 & 6 & 0,526 & neakceptovatelné \\
\hline LO & 15,07 & 3,13 & 16 & 1 & 20 & $-0,801$ & 0,695 & 0,748 & 0,763 & 0,589 & 9 & 0,763 & akceptovatelné \\
\hline NU & 12,34 & 3,17 & 13 & 1 & 20 & $-0,471$ & 0,645 & 0,714 & 0,716 & 0,480 & 8 & 0,716 & akceptovatelné \\
\hline $\mathrm{FC}$ & 9,94 & 2,31 & 10 & 0 & 14 & $-0,618$ & 0,572 & 0,633 & 0,655 & 0,461 & 6 & 0,655 & neakceptovatelné \\
\hline KI & 4,07 & 2,25 & 4 & 0 & 12 & 0,591 & 0,546 & 0,621 & 0,675 & 0,349 & 7 & 0,675 & neakceptovatelné \\
\hline
\end{tabular}

P-sebeprosazováni

\begin{tabular}{|c|c|c|c|c|c|c|c|c|c|c|c|c|c|}
\hline US & 16,01 & 3,01 & 17 & 2 & 20 & $-1,068$ & 0,709 & 0,770 & 0,767 & 0,473 & 8 & 0,770 & akceptovatelné \\
\hline TO & 11,10 & 1,96 & 11 & 1 & 14 & $-0,960$ & 0,568 & 0,632 & 0,643 & 0,428 & 6 & 0,643 & neakceptovatelné \\
\hline PR & 14,27 & 2,77 & 15 & & 20 & $-0,877$ & 0,578 & 0,682 & 0,718 & 0,271 & 8 & 0,718 & akceptovatelné \\
\hline NS & 10,06 & 2,20 & 10 & 1 & 14 & $-0,520$ & 0,496 & 0,580 & 0,637 & 0,352 & 7 & 0,637 & neakceptovatelné \\
\hline FM & 13,35 & 2,69 & 14 & 1 & 20 & $-0,560$ & 0,558 & 0,648 & 0,661 & 0,207 & 9 & 0,661 & neakceptovatelné \\
\hline
\end{tabular}

$N=4534$. Poznámka: $\mathrm{M}$ - průměr; SD - směrodatná odchylka; Md - medián; min, max - minimální a maximální pozorovaný skór; Sk - zešikmení škály; $\alpha$-Cronbachova alfa; $\lambda_{4}$ - maximální split-half reliabilita; $\mathrm{r}_{\mathrm{glb}}-$ koeficient GLB; $\beta$ - nejnižší split-half reliabilita; $\mathrm{nf}$ - počet faktorů využitých pro odhad koeficientů GLB a $\beta ; r_{\max }-$ vyšší z koeficientů $\lambda_{4}$ a $r_{g l b}$. 


\section{Vnitřní struktura a faktorová validita}

\section{H1: Jednodimenzionalita škál}

Dimenzionalita škál dotazníku SPARO byla problematická, na vině byly zejména celkově nízké korelace položek dotazníku; naprostá většina škál měla neakceptovatelné hodnoty indexu TLI, který se však do hodnocení nakonec promítl jen ojediněle kvůli slabým korelacím položek, a tedy i nízkým hodnotám RMSEA null základního modelu. Jednodimenzionální struktura byla pouze u tří škál (8\%) hodnocena jako dobrá, u 22 (55 \%) jako adekvátní a u 15 (38 \%) jako neakceptovatelná. Z hlavních komponent a obecnějších faktorů byla vnitřní struktura hodnocena jako dobrá u škály EM, jako adekvátní u škál RE a PV. Zbylé tři skóry nebyly jednodimenzionální.

Tabulka 3 obsahuje shodu jednotlivých modelů s daty.

\section{Tabulka 3}

Ukazatele shody jednodimenzionálních CFA modelůs daty

\begin{tabular}{llllllllll}
\hline \multicolumn{2}{c}{$\chi^{2}$} & df & TLI & RMSEA & {$[90 \%$ CI $]$} & SRMR & RMSEA $_{\text {null }}$ & hodnocení \\
\hline \multicolumn{7}{l}{ Hlavni komponenty } \\
KO & 2821,2 & 170 & 0,754 & 0,059 & {$[0,057 ; 0,061]$} & 0,081 & 0,118 & neakceptovatelné \\
EM & 1137,5 & 170 & 0,960 & 0,035 & {$[0,033 ; 0,037]$} & 0,047 & 0,177 & dobré \\
RE & 1607,1 & 170 & 0,851 & 0,043 & {$[0,041 ; 0,045]$} & 0,071 & 0,112 & adekvátní \\
AD & 934,2 & 170 & 0,651 & 0,031 & {$[0,030 ; 0,033]$} & 0,093 & 0,053 & neakceptovatelné
\end{tabular}

Obecné faktory

\begin{tabular}{llllllllll} 
PV & 575,5 & 77 & 0,921 & 0,038 & {$[0,035 ; 0,041]$} & 0,057 & 0,134 & adekvátní \\
MH & 1103,6 & 77 & 0,796 & 0,054 & {$[0,051 ; 0,057]$} & 0,082 & 0,120 & neakceptovatelné \\
\multicolumn{2}{l}{$\begin{array}{l}\text { N-Normalita } \\
\text { VZ }\end{array}$} & 653,6 & 90 & 0,869 & 0,037 & {$[0,035 ; 0,040]$} & 0,063 & 0,103 & adekvátní \\
LS & 1169,1 & 135 & 0,939 & 0,041 & {$[0,039 ; 0,043]$} & 0,059 & 0,166 & adekvátní \\
AN ${ }^{1}$ & & & & & & & \\
EX & 1164,9 & 170 & 0,454 & 0,036 & {$[0,034 ; 0,038]$} & 0,104 & 0,049 & neakceptovatelné
\end{tabular}

L-Skór věrohodnosti podávaných výpovědí

L $\quad 682,5 \quad 170 \quad 0,517 \quad 0,026 \quad[0,024 ; 0,028] \quad 0,080 \quad 0,037 \quad$ neakceptovatelné

S-Optimální hladina stimulace

$\begin{array}{lllllllll}\text { SI } & 2601,5 & 135 & 0,762 & 0,063 & {[0,061 ; 0,066]} & 0,085 & 0,130 & \text { neakceptovatelné } \\ \text { IP } & 2572,3 & 170 & 0,761 & 0,056 & {[0,054 ; 0,058]} & 0,090 & 0,114 & \text { neakceptovatelné } \\ \text { PN } & 2311,3 & 170 & 0,863 & 0,053 & {[0,051 ; 0,055]} & 0,081 & 0,142 & \text { neakceptovatelné } \\ \text { DI } & 1682,1 & 152 & 0,658 & 0,047 & {[0,045 ; 0,049]} & 0,073 & 0,081 & \text { adekvátní } \\ \text { SD } & 989,3 & 170 & 0,872 & 0,033 & {[0,031 ; 0,035]} & 0,062 & 0,091 & \text { adekvátní } \\ \text { OS } & 1770,9 & 170 & 0,909 & 0,046[0,044 ; 0,048] & 0,071 & 0,151 & \text { adekvátní }\end{array}$


$R$ - Tendence riskovat

$\begin{array}{llllllllll}\text { AS } & 1879,9 & 152 & 0,625 & 0,050 & {[0,048 ; 0,052]} & 0,087 & 0,082 & \text { neakceptovatelné } \\ \text { AC } & 2683,8 & 135 & 0,655 & 0,065 & {[0,062 ; 0,067]} & 0,102 & 0,110 & \text { neakceptovatelné } \\ \text { TN } & 1679,8 & 170 & 0,850 & 0,044 & {[0,042 ; 0,046]} & 0,079 & 0,114 & \text { adekvátní } \\ \text { SE } & 3391,1 & 170 & 0,728 & 0,065 & {[0,063 ; 0,067]} & 0,100 & 0,124 & \text { neakceptovatelné } \\ \text { OR } & 377,4 & 77 & 0,939 & 0,029 & {[0,026 ; 0,032]} & 0,058 & 0,118 & \text { adekvátní }\end{array}$

I-Účinná integrovanost

$\begin{array}{ccccccccc}\text { UZ } & 659,5 & 170 & 0,969 & 0,025 & {[0,023 ; 0,027]} & 0,044 & 0,143 & \text { dobré } \\ \text { EC } & 805,7 & 170 & 0,942 & 0,029 & {[0,027 ; 0,031]} & 0,059 & 0,119 & \text { adekvátní } \\ \text { UR } & 979,4 & 170 & 0,946 & 0,032 & {[0,030 ; 0,034]} & 0,052 & 0,139 & \text { adekvátní } \\ \text { RR } & 1289,7 & 170 & 0,817 & 0,038 & {[0,036 ; 0,040]} & 0,074 & 0,089 & \text { adekvátní } \\ \text { OI } & 795,8 & 170 & 0,960 & 0,028 & {[0,027 ; 0,031]} & 0,055 & 0,142 & \text { adekvátní } \\ \text { V-Vztahová } & \text { dimenze } & & & & & & \\ \text { KT } & 679,4 & 170 & 0,943 & 0,026 & {[0,024 ; 0,028]} & 0,052 & 0,108 & \text { adekvátní } \\ \text { BE } & 836,8 & 90 & 0,488 & 0,043 & {[0,040 ; 0,045]} & 0,073 & 0,060 & \text { adekvátní } \\ \text { KN } & 2196 & 170 & 0,515 & 0,051 & {[0,049 ; 0,053]} & 0,085 & 0,074 & \text { neakceptovatelné } \\ \text { NE } & 2244,8 & 170 & 0,503 & 0,052 & {[0,050 ; 0,054]} & 0,099 & 0,074 & \text { neakceptovatelné }\end{array}$

K- Korektivnost

$\begin{array}{lllllllll}\text { RF } & 2352,7 & 152 & 0,365 & 0,057 & {[0,055 ; 0,059]} & 0,123 & 0,071 & \text { neakceptovatelné } \\ \text { LO } & 1456,8 & 170 & 0,875 & 0,041 & {[0,039 ; 0,043]} & 0,069 & 0,115 & \text { adekvátní } \\ \text { NU } & 2296,7 & 170 & 0,770 & 0,053 & {[0,051 ; 0,054]} & 0,077 & 0,110 & \text { adekvátní } \\ \text { FC } & 514,2 & 77 & 0,876 & 0,035 & {[0,033 ; 0,038]} & 0,060 & 0,101 & \text { adekvátní } \\ \text { KI } & 221,9 & 77 & 0,975 & 0,020 & {[0,017 ; 0,024]} & 0,039 & 0,128 & \text { dobré } \\ \text { P-Sebeprosazovánín } & & & & & & & \\ \text { US } & 1368,9 & 170 & 0,911 & 0,039 & {[0,038 ; 0,041]} & 0,070 & 0,132 & \text { adekvátní } \\ \text { TO } & 323,2 & 77 & 0,931 & 0,027 & {[0,024 ; 0,030]} & 0,058 & 0,101 & \text { adekvátní } \\ \text { PR } & 2388,3 & 170 & 0,819 & 0,054 & {[0,052 ; 0,056]} & 0,077 & 0,126 & \text { adekvátní } \\ \text { NS } & 854,6 & 77 & 0,648 & 0,047 & {[0,044 ; 0,050]} & 0,071 & 0,080 & \text { adekvátní } \\ \text { FM } & 2568,4 & 170 & 0,700 & 0,056 & {[0,054 ; 0,058]} & 0,084 & 0,102 & \text { neakceptovatelné }\end{array}$

${ }^{1}$ Vzniká jako vážený součet škál a jednodimenzionalitu nelze předpokládat.

Pozn.: Všechny $\chi^{2}$ statistiky jsou signifikantní, p < 0,001. CI - interval spolehlivosti. RMSEA null $-R M S E A$ základního modelu (s předpokladem nekorelovaných položek). Pokud je menší než 0,158, je index TLI neinformativní (Kenny et al., 2014). 


\section{H2: Faktorová validita hlavních komponent SPARO}

Odhad čtyřfaktorového modelu ordinální konfirmační faktorové analýzy dosáhl hraniční shody modelu s daty, $\chi^{2}(3074)=17905, p<0,001, C F I=0,754, T L I=0,747, R M S E A=0,033$ s 90\% CI = [0,032, 0,033], SRMR =0,079. Nedostatečné velikosti indexů $C F I$ a $T L I$ nelze dobře interpretovat vzhledem k velmi nízkému $R M S E A$ základního modelu, $R M S E A_{\text {null }}=0,065$.

Inspekce modifikačních indexů a reziduální korelační matice navíc naznačila, že řada položek je pravděpodobně sycena jiným faktorem, než by měla být. Šlo o položky 134, 295, 71, 190 a 211 ze škály KO, které byly syceny faktory EM a AD, případně RE. Kromě položky 211 (,Rád se dívám do plamenư“) měly všechny na zbylých faktorech negativní modifikační index a byly zaměřené na výkon či vedoucí úlohu. Lze tedy předpokládat, že výše uvedené zkř̌́žené faktorové náboje způsobila sociální žádoucnost a zkreslení výpovědí respondentů v důsledku očekávané „správné“ odpovědi.

Rozhodli jsme se proto u těchto položek povolit nenulový faktorový náboj (crossloading) na všech čtyřech faktorech. Tato úprava modelu vedla $\mathrm{k}$ výraznému zlepšení shody modelu s daty, $\Delta \chi^{2}(15)=1570, p<0,001$ a mírně se zlepšily i indexy shody modelu s daty, $\chi^{2}(3059)=14403$, $p<0,001, C F I=0,812, T L I=0,806, R M S E A=0,029$ s 90\% $C I=[0,028,0,029], S R M R=0,069$. I v tomto modelu se objevovaly problematické položky s potenciálním faktorovým nábojem na jiných faktorech, ale $\mathrm{k}$ dalším úpravám jsme již nepřistoupili. Strukturní diagram a matice standardizovaných faktorových nábojů finálního modelu jsou dostupné v on-line supplementu.

Lze prohlásit, že faktorová struktura hlavních komponent SPARO byla částečně podpořena, a hlavní komponenty dotazníku SPARO jsou alespoň do jisté míry syceny samostatnými dimenzemi v souladu s předpoklady.

\section{H3: Nezávislost hlavních komponent dotazniku SPARO}

$\mathrm{V}$ původním faktorovém modelu spolu jednotlivé faktory velmi silně korelovaly, zejména faktory $\mathrm{AD}$ a $\mathrm{EM}, r_{A D-E M}=0,650$, RE a EM, $r_{R E-E M}=0,567$, a RE a AD, $r_{R E-A D}=0,438$. Faktor KO byl na ostatních faktorech méně závislý, všechny korelace byly nižší než 0,343 . Po úpravě modelu (povolení zkř́ižených faktorových nábojů) některé z korelací latentních proměnných dále vzrostly, např́iklad $\mathrm{u}$ faktorů $\mathrm{AD}$ a EM dokonce na $r_{A D-E M}=0,832$.

Ortogonální model bez povolených crossloadingů byl oproti původnímu modelu výrazně horší, $\Delta \chi^{2}(6)=1809,5, p<0,001$, a popisoval data zcela neuspokojivě, $\chi^{2}(3080)=27433,7, p<0,001$, CFI $=0,596, T L I=0,586, R M S E A=0,042 \mathrm{~s} 90 \% C I=[0,041,0,042], S R M R=0,113$. To stejné lze ř́́ci o modelu s povolenými crossloadingy, $\Delta \chi^{2}(6)=2031,3, p<0,001$, který rovněž data nepopisoval dobře, $\chi^{2}(3065)=25454,2, p<0,001, C F I=0,629, T L I=0,617, R M S E A=0,040 \mathrm{~s} 90 \% C I=[0,040$, $0,041], \mathrm{SRMR}=0,108$.

V obou prŕpadech bylo jediným přijatelným indexem RMSEA, což však bylo způsobeno celkově nízkými korelacemi položek (a tedy i nízkým $R M S E A_{\text {null }}$ úvodního modelu, viz výše). Lze uzavřít, že hlavní komponenty dotazníku SPARO nejsou vzájemně nezávislé a netvoří samostatné faktory tak, jak vyplývá z teoretických východisek. Relativně slabé korelace pozorovaných skórů (v rozmezí $0,01-0,36$ ) jsou způsobeny spíše nízkou reliabilitou než nezávislostí rysů.

\section{H4, H5: Faktorová validita obecnějších faktori̊}

Dvoudimenzionální konfirmační faktorový model složený z položek obecnějších faktorů PV a MH popsal data nepřijatelně, $\chi^{2}(349)=4722,5, p<0,001, C F I=0,711, T L I=0,687, R M S E A=, 053$ s $90 \% C I=[0,051,0,054], S R M R=0,102$. Jediným uspokojivým indexem je RMSEA, což je však 
zaprríčiněno celkově nízkými korelacemi a tedy i nízkým RMSEA nulového modelu, $R M S E A_{\text {null }}=0,094$. Na základě inspekce reziduální kovarianční matice a modifikačních indexů jsme nenalezli žádné potenciální úpravy, které by vedly k výraznějšímu zlepšení modelu.

Korelace obou faktorů byla relativně slabá, $r_{P V-M H}=-0,265, p<0,001$. Její omezení na nulu sice zhoršilo shodu modelu s daty, $\Delta \chi^{2}(1)=104,1, p<0,001$, nicméně zhoršení nebylo prŕliš věcně významné, $\chi^{2}(350)=4978,5, p<0,001, C F I=0,694, T L I=0,670, R M S E A=0,054 \mathrm{~s} 90 \% C I=[0,053$, $0,055], S R M R=0,111$.

Hypotézy H4 a H5 nebyly podpořeny, obecnější škály PV a MH nejsou syceny dvěma latentními faktory. Jejich korelaci tak nemá význam interpretovat.

\section{Zobecnitelnost závěrů}

\section{H6: Shoda originální korelační matice s našimi daty}

Korelační matice pozorovaná v našem vzorku se v případě mužů sice statisticky významně lišila od korelační matice reportované Mikšíkem (2009), ale rozdíl byl celkově spíše malý: $\chi^{2}(45)=405,8, p$ $<0,001, T L I=0,987, R M S E A=0,038 \mathrm{~s} 90 \% C I=[0,034,0,041], S R M R=0,029$.

V případě žen byly rozdíly matic ještě menší, ačkoli stále statisticky významné: $\chi^{2}(45)=197,8$, $\mathrm{p}<0,001, T L I=0,992, R M S E A=0,029 \mathrm{~s} 90 \% C I=[0,025,0,033], S R M R=0,026$.

Nad rámec hypotéz jsme prozkoumali rozdíly v korelačních maticích mužů a žen. V našem vzorku se statisticky významně nelišily, $\chi^{2}(45)=67,9, p=0,015, T L I=0,998, R M S E A=0,015 \mathrm{~s} 90 \% C I$ $=[0,007,0,022], S R M R=0,017$. V původním Mikšíkově (2009) vzorku byly rozdíly sice mírně větší a signifikantní, ale věcně zanedbatelné, $\chi^{2}(45)=775, p<0,001, T L I=0,980, R M S E A=0,046$ S 90\% CI = [0,043, 0,049], SRMR = 0,041. Faktorová struktura u mužů a žen je tedy prakticky shodná.

Mezi strukturou našich a originálních Mikšíkových (2009) dat není žádný věcně významný rozdíl, přinejmenším co se týče hlavních komponent, obecných faktorů a škál normality, a hypotéza H6 tak byla podpořena. Podrobné výsledky, včetně rozdílu v konkrétních korelacích a jejich statistické významnosti, jsou součástí on-line supplementu.

\section{Diskuze}

Předložené výsledky jsou společně s navazující studií (Cígler \& Rudá, 2021) podle nám dostupných informací prvním nezávislým výzkumem, který ověřoval psychometrické parametry dotazníku SPARO (Mikšík, 2004). Výsledky nejsou prŕiliš pozitivní.

\section{Vnitřní konzistence}

Námi pozorovaná reliabilita dotazníku SPARO je na vzorku policistů obdobná původním hodnotám uvedeným v manuálu metody (Mikšík, 2004), je však nutné podotknout, že reliabilita téměř poloviny škál nedosahuje akceptovatelných hodnot. Neuspokojivá je zejména vnitřní konzistence hlavní komponenty $\mathrm{AD}$ a obecnějšího faktoru $\mathrm{MH}$, které by měly být jedním z hlavních diagnostických vodítek. Ze stejných důvodů se nezdá být validní ani ipsativní interpretace dotazníku s pomocí 16 typů osobnosti navržených autorem metody, jejíž ověření však bylo nad možnostmi této studie.

Reliabilita hlavních komponent a obecnějších faktorů (s výjimkou AD) je zpravidla vyšší než u ostatních skórů. Př́ičinou může být fakt, že zatímco hlavní komponenty byly odvozovány na základě 
faktorové analýzy, což zajistilo alespoň určitou míru korelací např́ič položkami, ostatní škály byly vymezeny operacionálně (Mikšík, 2004, 2009), nikoli na základě vzájemných vztahů, a korelace tak mohou být nižší.

Reliabilita škál se nicméně zdá být celkově př́iliš nízká pro účely spolehlivé individuální diagnostiky. Nízká reliabilita snižuje možnosti souběžné a prediktivní validity škál, což dokládáme v navazující studii (Cígler \& Rudá, 2021). Za zmínku stojí i výrazně nižší hodnoty koeficientu $\beta$ (Revelle, 1978; Revelle \& Zinbarg, 2009), který udává reliabilitu odhadu prvního (a nejsilnějšího faktoru). Př́ičinou je složitá a vícedimenzionální faktorová struktura jednotlivých škál sycených nesourodou směsí mnoha osobnostních rysů, což souvisí s jejich neuspokojivou faktorovou validitou popisovanou dále.

\section{Vnitřní struktura a faktorová validita}

Naprostá většina škál dotazníku SPARO není ani přibližně jednodimenzionální. Vzhledem k multifasetové struktuře většiny konstruktů a jejich operacionálnímu vymezení nemusí jít o zásadní překážku při interpretaci výsledků dotazníků, limituje to však odhady vnitřní konzistence těchto škál prostřednictvím koeficientu alfa. Tento fakt je nutné brát v potaz v budoucích studiích.

Hlavním problémem je nicméně faktorová validita dotazníku SPARO jako celku. Ve shodě s autorem metody (Mikšík, 2001, 2004, 2009) lze sice konstatovat, že čtyři hlavní komponenty dotazníku jsou syceny čtyřmi samostatnými faktory (přestože při separátní analýze má u dvou škál model neakceptovatelnou shodu s daty), problematické jsou však korelace latentních proměnných. Mezi faktory AD, EM a RE jsme pozorovali středně silné až silné korelace, ačkoli na základě teorie bazální autoregulace osobnosti (Mikšík, 2001, 2004, 2009) by měly být nezávislé. To významným způsobem snižuje konstruktovou validitu dotazníku SPARO. Tyto korelace jsou zřejmě i prŕíčinou, proč komplexní čtyřdimenzionální model popsal data uspokojivě, zatímco dva z celkem čtyř jednodimenzionálních modelů měly neadekvátní shodu s daty. Chceme rovněž upozornit, že přinejmenším pět položek bylo syceno více faktory, ačkoli byly zařazeny do škály KO. Příčinou se zdá být sociální žádoucnost. Sociálně-žádoucí odpovídání v dotazníku SPARO by každopádně mělo být předmětem dalšího výzkumu, pokud by dotazník měl být i nadále používán v praxi.

V případě obecnějších faktorů PV a MH dokonce konstatujeme, že očekávaný dvoufaktorový model popsal data velmi špatně. V našem vzorku tak položky zařazené do škál PV a MH nejsou syceny dvěma nezávislými faktory, což je v ostrém rozporu s teoretickými předpoklady, a faktory psychické vzrušivosti (PV) a motorické hybnosti (MH) nelze interpretovat.

\section{Zobecnitelnost výsledků}

Naše výsledky jsou založeny výhradně na vzorku policistů a uchazečů o práci u policie a je tedy možné, že v jiných vzorcích dotazník SPARO může fungovat odlišně. To je však velmi nepravděpodobné: námi pozorované korelační matice u žen i mužů se totiž prakticky nelišily od korelačních matic reportovaných Mikšíkem (2009, pp. 116-118). Přestože rozdíly byly statisticky významné (vzhledem k velikosti vzorku, a tedy i extrémní statistické síle chí-kvadrát testu), po věcné stránce byly zcela zanedbatelné. Zdá se tedy, že námi použitý vzorek a vzorek použitý Mikšíkem pro vývoj dotazníku SPARO pochází ze stejné populace respondentů.

Jinými slovy, silné korelace latentních proměnných musely být přítomné už v původních vzorcích, na jejichž základě Mikšík $(2004,2009)$ tvrdil, že základní komponenty jsou ,relativně nezávislé“. Za zdánlivými slabými souvislostmi těchto škál tedy stála spíše jejich nízká vnitřní 
konzistence, která snižovala korelace pozorovaných skórů (na hodnoty klesající k 0,3 a níže), než skutečná nezávislost měřených latentních psychických rysů.

Naším vedlejším zjištěním pak bylo, že se prakticky neliší korelační matice mužů a žen (alespoň na úrovni celkových skórů). Zdá se proto, že není nezbytné faktorovou validitu a některé další parametry dotazníku ověřovat zvlášt' pro obě pohlaví.

\section{Shrnutí}

Pokud vezmeme v potaz veškeré naše výsledky, nenalezli jsme dostatek empirické podpory, že je dotazník SPARO validním nástrojem v kontextu policejní diagnostiky. Příliš velké množství škál má nedostatečnou reliabilitu, a to i pokud vezmeme v potaz jejich potenciálně vícedimenzionální strukturu. Rovněž se nám nepodařilo podpořit konstruktovou validitu hlavních skórů dotazníku, jejichž faktorová struktura se liší oproti teorii (Mikšík, 2001, 2004, 2009).

Na základě našich výsledků nelze doporučit používání metody SPARO u policejních sborů České republiky. Tento závěr je navíc pravděpodobně možné zobecnit na jiná typická použití dotazníku (nejen) v personalistice.

Pro validizaci diagnostické metody je nicméně klíčová rovněž i prediktivní a souběžná validita, v navazující studii (Cígler \& Rudá, 2021) proto ověříme souběžnou validitu proti dotazníku MMPI-2. Na rozdíl od dotazníku SPARO se lze u něj alespoň částečně spolehnout na rozsáhlý zahraniční výzkum, a proto se domníváme, že lze MMPI-2 považovat za relativně spolehlivé kritérium souběžné validity.

\section{Poděkování}

Tento článek vznikl za finanční podpory Grantové agentury České republiky v rámci projektu Metodické studie pro české verze měřítek psychologických charakteristik adolescentů a vynořujících se dospělých (GA17-09797S).

Chceme v první řadě poděkovat Policejnímu prezidiu České republiky za poskytnutí dat a dalších materiálů, bez kterých by tento článek nevznikl. Dále děkujeme Stanislavu Ježkovi za pomoc při úpravě struktury tohoto článku a Michaele Borovanské za pomoc při př́ípravě podkladů.

Doplňující výsledky, rozšiřující materiály, analytické skripty a další podklady jsou uvedeny v on-line supplementu dostupném na https://doi.org/10.17605/OSF.IO/CNU58.

\section{Literatura}

Bentler, P. M., \& Woodward, J. A. (1980). Inequalities among lower bounds to reliability: With applications to test construction and factor analysis. Psychometrika, 45(2), 249-267. https://doi.org/10.1007/BF02294079

Bentler, Peter M. (2009). Alpha, dimension-free, and model-based internal consistency reliability. Psychometrika, 74(1), 137-143. https://doi.org/10.1007/s11336-008-9100-1

Benton, T. (2015). An empirical assessment of Guttman's Lambda 4 reliability coefficient. In R. Millsap, D. Bolt, L. van der Ark, \& W. C. Wang (Eds.), Quantitative Psychology Research. Springer Proceedings in Mathematics \& Statistics, vol. 89 (pp. 301-310). Springer. https://doi.org/10.1007/978-3-319-07503-7

Cígler, H., \& Rudá, A. (2021). Souběžná validita dotazníku SPARO a MMPI 2. E-psychologie, 15(1), 40-68. https://doi.org/10.29364/epsy.392/ 
Corr, P. J., \& Matthews, G. (2009). The Cambridge handbook of personality psychology. Cambridge University Press.

Cronbach, L. J. (1951). Coefficient alpha and the internal structure of tests. Psychometrika, 16(3), 297334. https://doi.org/10.1007/BF02310555

Guttman, L. (1945). A basis for analyzing test-retest reliability. Psychometrika, 10(4), 255-282. https://doi.org/10.1007/BF02288892

Hu, L., \& Bentler, P. M. (1999). Cutoff criteria for fit indexes in covariance structure analysis : Conventional criteria versus new alternatives. Structural Equation Modeling, 6(1), 1-55. https://doi.org/10.1080/10705519909540118

Jorgensen, T. (2020). Function lavTestLRT() for Model Comparison. [Online forum post]. Google Groups. https://groups.google.com/forum/\#!topic/lavaan/nNFcxgzodAs

Jorgensen, T. D., Pornprasertmanit, S., Schoemann, A. M., \& Rosseel, Y. (2020). semTools: Useful tools for structural equation modeling (0.5-3). https://cran.r-project.org/package=semTools

Jurišová, E., \& Sarmány-Schuller, I. (2013). Structure of basal psychical self-regulation and personality integration in relation to coping strategies in decision-making in paramedics. Studia Psychologica, 55(1), 3-18. https://doi.org/10.21909/sp.2013.01.617

Kenny, D. A., Kaniskan, B., \& McCoach, D. B. (2014). The performance of RMSEA in models with small degrees of freedom. Sociological Methods \& Research, 44(3), 486-507. https://doi.org/10.1177/0049124114543236

Kuder, G. F., \& Richardson, M. W. (1937). The theory of the estimation of test reliability. Psychometrika, 2(3), 151-160. https://doi.org/10.1007/BF02288391

Lakens, D. (2017). Equivalence tests. Social Psychological and Personality Science, 8(4), 355-362. https://doi.org/10.1177/1948550617697177

Leary, M. R., \& Hoyle, R. H. (Eds.). (2009). Handbook of individual differences in social behavior. The Guilford Press.

MacCallum, R. C., Browne, M. W., \& Sugawara, H. M. (1996). Power analysis and determination of sample size for covariance structure modeling. Psychological Methods, 1(2), 130-149. https://doi.org/10.1037//1082-989X.1.2.130

Mangiafico, S. (2020). rcompanion: Functions to Support Extension Education Program Evaluation (R package version 2.3.21). https://cran.r-project.org/package=rcompanion

Marko, M. (2016). Využitie a zneužitie Cronbachovej alfy pri hodnotení psychodiagnostických nástrojov. TESTFÓRUM, 5(7). https://doi.org/10.5817/TF2016-7-90

McDonald, R. P. (1999). Test theory: A unified treatment. Lawrence Erlbaum Associates, Inc.

Mikšík, O. (1992). IHAVEZ - SPIDO - VAROS (přiručka). Psychodiagnostika.

Mikšík, O. (2001). Zjištování bazální struktury a dynamiky autoregulace, integrovanosti a psychické odolnosti osobnosti dotazníky SPARO, BAROM, IHATRANS (manuál). Diaros.

Mikšík, O. (2003). Psychologické teorie osobnosti. Karolinum.

Mikšík, O. (2004). Dotazník SPARO (přiručka). Psychodiagnostika.

Mikšík, O. (2007). Psychologická charakteristika osobnosti. Karolinum.

Mikšík, O. (2009). Psychika osobnosti v období závažných životních a společenských změn. Karolinum.

Phillips, N. (2017). yarrr: A Companion to the e-Book "YaRrr!: The Pirate's Guide to R" (R package version 0.1.5). https://cran.r-project.org/package=yarrr

Preiss, J., \& Haas, T. (1997). Některé psychometrické charakteristiky české verze Washingtonského psychosociálního dotazníku pro záchvatová onemocnění (WPSI). Československá psychologie, $41(4), 334-346$.

$\mathrm{R}$ Core Team. (2020). R: A language and environment for statistical computing. R Foundation for Statistical Computing.

Raykov, T. (1997). Estimation of composite reliability for congeneric measures. Applied Psychological Measurement, 21(2), 173-184. https://doi.org/10.1177/01466216970212006

Revelle, W. (1978). Hierarchical cluster analysis and the internal structure of tests. Multivariate Behavioral Research, 14(1), 57-74. https://doi.org/10.1207/s15327906mbr1401_4 
Revelle, W. (2019). psych: Procedures for Personality and Psychological Research (1.9.12). Northwestern University. https://cran.r-project.org/package=psych

Revelle, W., \& Zinbarg, R. E. (2009). Coefficients Alpha, Beta, Omega, and the glb: Comments on Sijtsma. Psychometrika, 74(1), 145-154. https://doi.org/10.1007/s11336-008-9102-z

Rosseel, Y. (2012). lavaan: An R Package for structural equation modeling. Journal of Statistical Software, 48(2), 1-36. http://www.jstatsoft.org/v48/102/

Satorra, A. (2000). Scaled and Adjusted Restricted Tests in Multi-Sample Analysis of Moment Structures (pp. 233-247). Springer US. https://doi.org/10.1007/978-1-4615-4603-0_17

Signorell, A., \& et al. (2020). DescTools: Tools for descriptive statistics (R package version 0.99.32). https://cran.r-project.org/package=DescTools

Sijtsma, K. (2009). On the use, the misuse, and the very limited usefulness of Cronbach's Alpha. Psychometrika, 74(1), 107-120. https://doi.org/10.1007/s11336-008-9101-0

Šucha, M., Št’astná, L., \& Zámečník, P. (2017). Osobnostní vlastnosti řidičů řídících pod vlivem alkoholu. Adiktologie, 17(1), 34-44.

Svoboda, M., Řehan, V., Vtípil, Z., Klimusová, H., Humpolíček, P., Urbánek, T., \& Kouhoutek, T. (2004). Aplikovaná psychodiagnostika v České republice. MSD.

Torchiano, M. (2019). effsize: Efficient Effect Size Computation (R package version 0.7.6). https://doi.org/10.5281/zenodo.1480624

Urbánek, T. (2010). Nejpoužívanější psychodiagnostické metody v České republice. TESTFÓRUM, 1(1), 6-9. https://doi.org/10.5817/TF2010-1-3

Wickham, H., \& Bryan, J. (2019). readxl: Read Excel Files (R package version 1.3.1). https://cran.rproject.org/package $=$ readxl

\section{Údaje o autorech}

Mgr. Hynek Cígler, PhD. přednáší na katedře psychologie a je výzkumným pracovníkem v Institutu výzkumu dětí, mládeže a rodiny, Fakulta sociálních studií Masarykovy univerzity.

(iD) https://orcid.org/0000-0001-9959-6227

\section{Kontaktní údaje}

Adresa: Katedra psychologie, Fakulta sociálních studií Masarykovy univerzity, Joštova 10, 60200 Brno

E-mail: hynek.cigler@mail.muni.cz

Mgr. Adéla Rudá vystudovala psychologii na Filozofické fakultě Univerzity Karlovy v Praze. Pracovala jako psycholožka na Policejním prezidiu ČR, nyní působí v soukromé praxi.

\section{Kontaktní údaje}

Email: adela.ruda@seznam.cz

Cígler, H., \& Rudá, A. (2021). Reliabilita a faktorová validita dotazníku SPARO. E-psychologie, 15(1), 1639. https://doi.org/10.29364/epsy.391 


\section{Př́lohy}

\section{Př́loha 1: Škály dotazníků VAROS, SPIDO a IHAVEZ}

\section{Tabulka 1.1}

Vývoj škál např́č dotazníky VAROS, SPIDO a IHAVEZ

\begin{tabular}{|l|c|c|}
\hline & VAROS & SPIDO a IHAVEZ \\
\hline KO - Kognitivní variabilnost & $\mathrm{x}$ & $\mathrm{x}$ \\
\hline EM - Emocionální variabilnost & $\mathrm{x}$ & $\mathrm{x}$ \\
\hline RE - Reakční variabilnost & $\mathrm{x}$ & $\mathrm{x}$ \\
\hline AD - Adjustační variabilnost & $\mathrm{x}$ & $\mathrm{x}$ \\
\hline OV/PV - Obecná hladina psychické vzrušivosti & $\mathrm{x}$ & $\mathrm{x}$ \\
\hline MH - Motorická hybnost & $\mathrm{x}$ & $\mathrm{x}$ \\
\hline EX - Inventář extrémních odpovědí & $\mathrm{x}$ & $\mathrm{x}$ \\
\hline KR - Kognitivní regulační variabilnost & & $\mathrm{x}$ \\
\hline ER - Emocionální regulační variabilnost & & $\mathrm{x}$ \\
\hline KA - Kognitivní adjustační variabilnost & & $\mathrm{x}$ \\
\hline EA - Emocionální adjustační variabilnost & & $\mathrm{x}$ \\
\hline RA - Regulační adjustační variabilnost & & $\mathrm{x}$ \\
\hline FM - Maskulinita / Feminita & & $\mathrm{x}$ \\
\hline US - Usedlost, bezstarostnost & & \\
\hline
\end{tabular}

Poznámka: Přídavné škály dotazníky IHAVEZ tvoří: S1 - Smyslová imprese, S2 - Intenzita vnitřního prožívání, S3 Pohybový neklid, S4 - Dynamičnost a interakce s prostředím, S5 - Sociální desinhibice, SG - Obecná dimenze optimální hladiny stimulace, R1 - Úroveň aspirace, R2 - Hladina anticipace, R3 - Tendence spoléhat se na náhodu, R4 - Sociální exhibicionismus, RG - Obecná dimenze individuální tendence k riziku, SR - SR, I1 - Úzkostnost, I2 - Emocionalita, I3 - Účinná kapacita rozumu, I4 - Hladina resistence vůči rušivým podnětům, IG - Globální škála I-1 až I-3, P1 Sebejistota, P2 - Adaptabilita a flexibilita, P3 - Odpovědnost, P4 - Aktivnost, K - Skór krajních odpovědí. 
Tabulka 1.2

Seznam všech škál dotazníku SPARO

\begin{tabular}{|c|c|c|c|c|c|c|}
\hline N: Normalita & $\begin{array}{c}\text { S: Optimální } \\
\text { hladina } \\
\text { stimulace }\end{array}$ & $\begin{array}{l}\text { R: Tendence } \\
\text { riskovat }\end{array}$ & $\begin{array}{c}\text { I: Účinná } \\
\text { integrovanost }\end{array}$ & $\begin{array}{c}\text { V: Vztahová } \\
\text { dimenze }\end{array}$ & K: Korektivnost & $\begin{array}{c}\text { P: } \\
\text { Sebeprosazení }\end{array}$ \\
\hline $\begin{array}{c}\text { VZ: } \\
\text { vZtahovačnost }\end{array}$ & $\begin{array}{c}\text { SI: smyslová } \\
\text { imprese }\end{array}$ & $\begin{array}{c}\text { AS: úroveň } \\
\text { aspirací }\end{array}$ & UZ: úzkostlivost & $\begin{array}{l}\text { KT: uzavřenost } \\
\text { versus } \\
\text { kontaktivnost }\end{array}$ & $\begin{array}{c}\text { RF: rigidita } \\
\text { versus flexibilita }\end{array}$ & $\begin{array}{l}\text { US: potlačená } \\
\text { vs. vysoká } \\
\text { sebejistota }\end{array}$ \\
\hline $\begin{array}{l}\text { LS: psychická } \\
\text { labilita versus } \\
\text { stabilita }\end{array}$ & $\begin{array}{l}\text { IP: intenzita } \\
\text { vnitřního } \\
\text { prožívání }\end{array}$ & $\begin{array}{l}\text { AC: hladina } \\
\text { anticipace }\end{array}$ & EC: emotivita & $\begin{array}{c}\text { BE: hladina } \\
\text { benevolence a } \\
\text { tolerance }\end{array}$ & $\begin{array}{c}\text { LO: } \\
\text { lehkomyslnost vs. } \\
\text { odpovědnost }\end{array}$ & $\begin{array}{c}\text { TO: } \\
\text { trudomyslnost } \\
\text { vs. sebedůvěra }\end{array}$ \\
\hline $\begin{array}{l}\text { AN: úroveň } \\
\text { anomálie }\end{array}$ & $\begin{array}{l}\text { PN: pohybový } \\
\text { neklid }\end{array}$ & $\begin{array}{l}\text { TN: tendence } \\
\text { spoléhat na } \\
\text { náhodu }\end{array}$ & $\begin{array}{c}\text { UR: účinná } \\
\text { kapacita rozumu }\end{array}$ & $\mathrm{KN}$ : konformita & $\begin{array}{c}\text { NU: nevázanost } \\
\text { vs. usedlost }\end{array}$ & $\begin{array}{l}\text { PR: prožitkový } \\
\text { vs. činnostní } \\
\text { přístup }\end{array}$ \\
\hline \multirow[t]{3}{*}{$\begin{array}{c}\text { EX: extremita } \\
\text { výpovědí }\end{array}$} & $\begin{array}{c}\text { DI: dynamičnost } \\
\text { interakcí } \\
\text { s prostředím }\end{array}$ & $\begin{array}{c}\text { SE: sociální } \\
\text { exhibitovanost }\end{array}$ & $\begin{array}{c}\text { RR: resistence vůči } \\
\text { rušení }\end{array}$ & $\begin{array}{l}\text { NE: tendence } \\
\text { k nezávislosti }\end{array}$ & $\begin{array}{l}\text { FC: frustrovanost } \\
\text { vs. cílesměrnost }\end{array}$ & $\begin{array}{c}\text { NS: } \\
\text { nenápadnost } \\
\text { vs. } \\
\text { sebeprosazení }\end{array}$ \\
\hline & $\begin{array}{c}\text { SD: sociální } \\
\text { disinhibitovanost }\end{array}$ & $\begin{array}{l}\text { OR: obecný } \\
\text { trend riskovat }\end{array}$ & $\begin{array}{c}\text { OI: obecná úroveň } \\
\text { integrovanosti }\end{array}$ & & $\begin{array}{l}\text { KI: korigovanost } \\
\text { vs. impulsívnost }\end{array}$ & $\begin{array}{l}\text { FM: femininní } \\
\text { vs. maskulinní } \\
\text { interakce }\end{array}$ \\
\hline & $\begin{array}{c}\text { OS: obecná } \\
\text { stimulační } \\
\text { hladina }\end{array}$ & & & & & \\
\hline
\end{tabular}




\section{Př́iloha 2: Zařazení položek do škál}

Správnost zařazení položek do škál byla ověřena pomocí vizuální inspekce bodových grafů, které srovnávaly skóry škál exportované $\mathrm{z}$ administračních systémů se skóry ručně vytvořenými z odpovědí na jednotlivé položky (viz on-line supplement). Kromě toho byly pro každou škálu oba druhy skórů vzájemně srovnány Pearsonovou korelací. Všechny korelace byly rovné jedné, a tedy položky byly správně zařazené. Výjimkou byla škála $A D$ vzniklá jako vážený součet subškál, kde korelace byla ,pouze“ $r=0,992$. K tomu došlo tím způsobem, že postup popsaný v manuálu metody (Mikšík, 2004, pp. 90-91) používá vážené skóry, které jsme však neměli k dispozici. Proto jsme váhy odvodili empiricky s pomocí lineární regrese, kde prediktory byly příslušné subtesty tvořící škálu AN a pozorovaný skór škály AN byl závislou proměnnou. To vedlo k dokonale lineárnímu vztahu a $r=1,0000$. Použité váhy subtestů tedy jsou:

$$
\begin{gathered}
A N=6.36212172-0,16800000 \cdot A D+0,06111111 \cdot S E-0,10067114 \cdot R R \\
-0,05833333 \cdot U S+0,34463276 \cdot L-0,09633028 \cdot N S \\
+0,36269430 \cdot E X-0,09459460 \cdot T O-0,20000000 \cdot N E
\end{gathered}
$$

namísto originálního

$$
\begin{gathered}
A N=-0,4 \cdot A D+0,2 \cdot S E-0,3 \cdot R R-0,2 \cdot U S+0,6 \cdot L-0,2 \cdot N S+0,7 \\
\cdot E X \quad-0,2 \cdot T O-0,5 \cdot N E
\end{gathered}
$$

Oboje váhy však byly velmi podobné, při srovnání Pearsonovým korelačním koeficientem $r=0,991$. 


\section{Př́loha 3: Odhad vnitřní konzistence}

Pro odhad vnitřní konzistence škál jsme použili několik různých koeficientů, všechny byly odhadnuté v knihovně psych (Revelle, 2019). Prvním z nich je Cronbachovo alfa (Cronbach, 1951), které je v př́padě binárních položek shodné s tzv. koeficientem KR-20 (Kuder \& Richardson, 1937). Tento koeficient však předpokládá jednodimenzionální strukturu testu a tau-ekvivalenci položek (tedy jejich shodný faktorový náboj na prvním a zároveň jediném faktoru), což může vést ke značnému podhodnocení skutečné reliability (Peter M. Bentler, 2009; Marko, 2016; Raykov, 1997; Revelle \& Zinbarg, 2009; Sijtsma, 2009). Koeficient alfa proto reportujeme jen pro účely srovnání s dřívějšími odhady a v následujícím textu jej uvádíme jako $\alpha$.

Pro testy s vícedimenzionální strukturou a kongenerickými položkami (rozdílné faktorové náboje i reziduální rozptyly) jsou výhodnější jiné koeficienty, které poskytují méně zkreslený odhad skutečné vnitřní konzistence. Všechny jsou označovány jako nejvyšší spodní hranice reliability, glb (Peter M. Bentler, 2009; Revelle \& Zinbarg, 2009; Sijtsma, 2009).

Jedním z nich je tzv. nejvyšší split-half reliabilita. Při tomto postupu je prvně test rozdělen na dvě poloviny takovým způsobem, který maximalizuje kovarianci obou polovin, a následně je použita Guttmanova (1945) lambda-4 pro odhad reliability celého testu (Benton, 2015; Revelle \& Zinbarg, 2009). Pro odhad byla využita funkce splitHalf v balíčku psych, která ve škálách do 16 položek ověří všechna možná rozdělení, v delších škálách použivá různé iterativní procesy. Koeficient anotujeme jako $\lambda_{4}$.

Bohužel, koeficient $\lambda_{4}$ vykazuje pozitivní zkreslení při menších vzorcích a nižší skutečné reliabilitě (Benton, 2015). Z toho důvodu reportujeme rovněž Bentlerův (P. M. Bentler \& Woodward, 1980; Peter M. Bentler, 2009; Revelle \& Zinbarg, 2009; Sijtsma, 2009) koeficient glb, který je založený na odhadu prostřednictvím explorační faktorové analýzy s takovým počtem faktorů, který ještě nevede $\mathrm{k}$ negativní vlastní hodnotě žádného $\mathrm{z}$ extrahovaných faktorů. $\mathrm{V}$ tomto případě je tedy podobný McDonaldově (1999) celkovému koeficientu omega $\left(\omega_{t}\right)$, avšak nevyžaduje apriorní stanovení požadovaného počtu faktorů. Pro odhad je použit postup odhadu s pomocí kovarianční matice tak, jak je implementován ve funkci glb. fa v balíčku psych. Koeficient anotujeme jako $r_{g l b}$. Pro účely reportování celkové vnitřní konzistence subškál jsme pak použili vyšší z koeficientů $\lambda_{4} \mathrm{a}$ $r_{g l b}$, který anotujeme jako $r_{\max }$.

Koeficienty $\lambda_{4}$ a $r_{g l b}$ lze chápat jako očekávanou test-retest reliabilitu paralelních testů, př́padně jako rozptyl pozorovaného skóru vysvětlený všemi latentními proměnnými, případně jako relativní nepř́itomnost unikátního (chybového) rozptylu položek na celkovém skóre - to vše za předpokladu, že unikátní rozptyl položek není systematický. Pro mnoho účelů ale může být výhodné zjistit, kolik rozptylu celkového skóre vysvětluje výhradně první faktor; jinými slovy, jaký vliv na součet všech položek má jediná latentní proměnná, kterou můžeme měřit (bez ohledu na další systematické vlivy, sdílené několika, nikoli však všemi položkami). Za tímto účelem jsme použili Revellovu (1978) betu, která je označována jako nejhorší split-half reliabilita (Revelle \& Zinbarg, 2009). Jde o nejmenší možný podíl rozptylu, který je nezbytně vysvětlený společnou příčinou všech položek. Koeficient byl odhadnut rovněž pomocí funkce splitHalf v balíčku psych a anotujeme jej jako $\beta$. Všechny uvedené koeficienty byly odhadnuty s pomocí kovarianční, nikoli korelační matice. 


\section{Škála SPARO: Anomálie osobnosti (AN)}

Škála AN v metodě SPARO vzniká jako lineární kombinace devíti různých skórů (1 komponenta a 8 škál). Těchto devět škál je přitom tvořen celkem 168 položkami, z nichž se však 49 opakuje přinejmenším dvakrát $\mathrm{v}$ různých škálách, unikátních položek je pouze 118. Pro odhad vnitřní konzistence jsme proto použili př́mo rekódované položky, kdy každá z položek vznikla jako vážený skór originálních položek podle stejného vzorce, jakým se počítá škála AN. Oba postupy vedou ke stejnému skóre škály AN, náš postup však umožňuje odhad vnitřní konzistence přímo nad kovarianční maticí položek za využití výše uvedených postupů (koeficienty $\alpha, \lambda_{4}, r_{g l b}, r_{\max } \mathrm{a} \beta$ ). 